\title{
PERAN KHUSUS VERBA "MEMASAK" DALAM BAHASA BALI: KAJIAN METABAHASA SEMANTIK ALAMI (MSA)
}

\author{
Ida Bagus Pramana Pidada \\ email: gusramanda@gmail.com, \\ Program Magister Linguistik, Universitas Udayana \\ I Nengah Sudipa, \\ email: nengahsudipa@yahoo.co.id., \\ Program Magister Linguistik, Universitas Udayana \\ Ni Made Suryati \\ email: suryati.jirnaya@yahoo.com \\ Program Magister Linguistik, Universitas Udayana
}

\begin{abstract}
Abstrak-Penelitian tentang Peran Khusus Verba Memasak Bahasa Bali (VMBB) : Kajian Metabahasa Semantik Alami ini mengkaji aspek semantik, yakni realisasi leksikal dan klasifikasi verba "memasak" dalam bahasa Bali (VMBB) terutama peran khusus semantik argumen VMBB. Penentuan peran-peran argumen VMBB menggunakan teori Peran Umum (Macroroles) mengkaji peran semantik VMBB. Secara umum, ACTOR di dalam VMBB bertindak sebagai agen, UNDERGOER bertindak sebagai pasien. Analisis peran dalam penelitian ini dilakukan secara berlapis untuk menentukan sebuah peran semantik pada argumen tertentu. Kajian penelitian ini menggunakan rancangan penelitian kualitatif, sedangkan pengumpulan data dilakukan dengan metode observasi, wawancara, perekaman, dan pencatatan. Analisis data dilakukan dengan metode distribusional dengan teknik penggantian (substitusi). Teknik lanjutannya adalah mendeskripsikan peran khusus verba memasak dalam bahasa Bali (VMBB). Analisis dibantu dengan teknik eksplikasi. Penyajian hasil analisis data dilakukan dengan metode deskripsi, formal, dan informal. Leksikon Verba Memasak Bahasa Bali (VMBB) ditemukan sebanyak 12 butir yakni nyakan,mubuh, ngoreng, ngepes, ngnyahnyah, nadang, nunu, nambus, ngatim, nguskus, nguling, dan nglablab. Hasil penelitian menunjukkan bahwa leksikon-leksikon VMBB memiliki peran khusus yakni sebagai agen dan pasien.
\end{abstract}

Kata Kunci- Peran khusus dan verba memasak

Abstract-Observasion of Special Role of Verba"Memasak"' Bali Language (VMBB): Metalanguage Analysis of Natural Semantic analyses semantic aspect, firstly lexical realization and verb classification "memasak" in Bali langage (VMBB) mainly special role of argument semantic VMBB. Determination of the argument roles VMBB using theory of general role (Macroroles) analyses semantic role VMBB. Im general, ACTOR in VMBB acts as agent, UNDERGOER act as patient. Role analyses in this observation are done in layers to determine a semantic in an argument. The analyses of this observation use the design of qualitative observation, meanwhile the collection of data is done by observation method, interview, recording, and noting. Data analysis is done by 
distributional method by using replacement technique (substitution). The next method is description of special role of verb "memasak" in Bali language (VMBB). Analysis is assisted with explication technique. The presentation of result analysis of the data is done by the method of description, formal, and informal. Lexicon of verba"memasak" in Bali language (VMBB) is found 12 firstly: nyakan,mubuh, ngoreng, ngepes, ngnyahnyah, nadang, nunu, nambus, ngatim, nguskus, nguling, and nglablab.The result of observation shous that the lexion of VMBB have special role firstly as agent and patient.

Keywords — Specific role and verb "memasak"

\section{PENDAHULUAN}

Bahasa Bali adalah sebagai bahasa pertama yang digunakan dan diajarkan baik di keluarga, sekolah, maupun di lingkungan sekitar tempat tinggal sebagai bahasa pengantar dalam interaksi antar sesama anggota masyarakat (Samsuri,1987 : 7). Di samping itu bahasa Bali juga berkedudukan sebagai: (1) lambang kebanggaan daerah, (2) lambang identitas daerah, (3) sarana perhubungan di dalam keluarga dan masyarakat daerah, dan (4) sarana pengembangan serta pendukung kebudayaan daerah (Sudipa, 2010:1).

Dalam bidang kesenian, bahasa Bali memiliki peranan cukup penting sebagai penyalur atau ungkapan ekspresi masyarakat penggemar seni terutama kesenian tradisional khas Bali. Adapun kesenian Bali yang menggunakan bahasa Bali sebagai medianya adalah drama gong, arja, topeng, dan janger (Bawa dan Jendra,1981 : 7).

Selain itu, bahasa Bali juga memiliki dua variasi yang berbeda yakni Basa Bali Alus dan Basa Bali Kasar (Pastika, 1999: 1). Verba 'memasak' adalah salah satu jenis verba bahasa Bali yang merupakan verba dengan beberapa leksikon serta memiliki unsur-unsur makna khas yang terkandung di dalamnya. Selain itu, verba 'nyakan' mengandung banyak keunikan sehingga sangat menarik untuk dikaji dan diteliti. Salah satu di antaranya adalah penggunaan leksikon yang berbeda dengan medan makna yang sama seperti : mubuh, ngoreng, dan sebagainya yang disebabkan oleh 'tujuan' dilakukannya tindakan sesuai dengan apa yang dikatakan oleh verbanya.

Menurut Chomsky (1977 : 40) sebagai kompetensi penutur asli, yang meliputi kompetensi linguistik dan kompetensi pragmatik. Dari dua kompetensi linguistik yang telah disebutkan tersebut, memungkinkan peneliti dalam membuat penelitian intuitif apakah suatu kalimat di dalam bahasa Bali berterima (gramatikal) atau tidak.

Peran semantik merupakan sebuah peran yang ditemukan dalam argumen predikat dan oleh karena hal ini dikatakan menawarkan sebuah hubungan secara semantis antara argumen dan predikat (Van Vallin dan Lapolla,1999:141). Booij (2007:191) menyatakan peran semantik adalah generalisasi tentang peran partisipan dalam peristiwa yang ditunjukan oleh verba.

Secara umum, peran-peran yang dimainkan oleh argumen verba adalah subjek sebagai ACTOR dan objek sebagai UNDERGOER. Secara lebih mendalam, peran ACTOR dan UNDERGOER tersebut 
memiliki peran bawahan masing-masing, akan tetapi peran bawahan yang dimainkan akan berbeda tergantung dari tujuan digunakannya verba.

Beberapa penjelasan secara singkat mengenai peran semantik verba 'memasak' dalam bahasa Bali maka dapat dikatakan sangat menarik untuk diteliti.

\section{METODE PENELITIAN}

Tujuan penelitian dapat dicapai karena peneliti mengembangkan suatu strategi bahwa penutur tertentu menggunakan verba "memasak" khusus pada situasi alami tertentu. Dalam hal ini, terdapat sejumlah model pertanyaan yang dirumuskan, yang menyangkut bentuk-bentuk ekspresi yang mencerminkan tindakan "memasak", padanan atau terjemahannya, faktor pemicunya, wujud dan caranya, serta sasarannya.

Lokasi penelitian diperoleh dari beberapa kabupaten / kota dengan diwakili oleh kecamatan dan desa dengan tujuan untuk menghimpun data berupa tuturan kalimat yang berisikan leksikon verba "memasak" bahasa Bali. Dengan demikian, data kalimat yang didapatkan dari seluruh kabupaten, kecamatan, dan desa dihimpun sebanyak-banyaknya kemudian dinilai dan dibandingkan keabsahannya dengan beberapa orang informan kunci yang berbeda, serta dinilai kebenarannya secara intuitif.

Data primer yang berupa ujaran lisan penutur bahasa Bali dapat diperoleh melalui teknik wawancara dan observasi di lapangan. Berkenaan dengan hal ini, peneliti menyiapkan beberapa instrumen untuk kepentingan wawancara dan observasi. Dalam menganalisis data digunakan metode distribusional, yang terjabar dalam teknik dasar dan teknik lanjutan. Metode distribusional adalah metode yang alat penentunya bagian dari bahasa yang bersangkutan. Dengan kata lain, kata bantu dalam metode distribusional berupa bagian atau unsur dari bahasa objek sasaran penelitian itu sendiri seperti kata, frasa, dan klausa (Sudaryanto, 1985: 4 - 5).

Penyajian hasil analisis data menggunakan teknik induktif merupakan teknik yang mengkaji data dengan pola khusus ke pola umum (Hadi, 1981:42) Peneliti mengkaji verba "nyakan" bahasa Bali menggunakan teknik induktif, yakni verba "nyakan" sebagai pola khusus sedangkan peran semantis sebagai pola umum.

\section{HASIL PENELITIAN DAN PEMBAHASAN}

Verba Memasak Bahasa Bali (VMBB) dikaji dengan teori Metabahasa Semantik Alami (MSA) untuk menjelaskan makna asali khususnya verba memasak bahasa Bali (VMBB). Sudipa (2004:287) menjelaskan ciri khas setiap leksikon didasarkan atas entitas dan cara yang dikenai tindakan, serta akhir yang diharapkan oleh agen.

Leksikon VMBB dengan entitas berupa makanan dapat direalisasikan sebagai jakan, kukus dan tepeng. Leksikon-leksikon ini dikelompokkan menjadi satu karena memiliki kemiripan ciri menonjol, yakni kemiripan entitas berupa makanan. Meskipun demikian, leksikon-leksikon tersebut tetap saja memiliki perbedaan pada makna antara makna satu dengan makna lainnya. Perbedaan tersebut terletak pada instrumen yang digunakan dengan cara mengolah maupun hasil yang diinginkan. 
Untuk mendapatkan gambaran yang jelas mengenai leksikon-leksikon tersebut.

Selanjutnya, peran khusus argumen Verba Memasak Bahasa Bali (VMBB) dipaparkan pada data berikut.

\section{(2.1) Luh Sari nyakan nasi di paon}

Nama memasak nasi di dapur

'Luh Sari memasak nasi di dapur'

\section{A/agen U/pasien}

Peran semantis yang diduduki oleh masing-masing argumen menunjukkan peran khusus. Pada data (2.1) terdiri dari dua argumen yang memiliki peran sebagai agen dan pasien. Luh Sari menduduki peran sebagai agen, karena melakukan pekerjaan nyakan dengan proses dari beras menjadi nasi, sedangkan nasi memiliki peran khusus yakni sebagai pasien.

\section{(2.2) Nyoman Rempeg mubuh baas baanga panak-panak-né}

Nama memasak beras diberikan anakanaknya-POSS

Data (2.2) terdiri dari dua argumen yang memiliki peran sebagai agen dan pasien. Nyoman Rempug menduduki peran sebagai agen, karena melakukan pekerjaan nyakan dengan proses dari beras menjadi nasi, sedangkan nasi memiliki peran khusus yakni sebagai pasien.

\section{(2.3)Nyoman Winda nunu sera di jalikan-né} Nama memanggang terasi di tungku masaknya-POSS

'Nyoman Winda memanggang terasi di tungku masaknya'
A/agen
U/pasien

Data (2.3) terdiri dari dua argumen yang memiliki peran sebagai agen dan pasien. Nyoman Winda menduduki peran sebagai agen, karena melakukan pekerjaan пипи (memanggang) dengan proses dari sera (terasi) menjadi sera matunu (terasi yang dipanggang), sedangkan sera (terasi) memiliki peran khusus yakni sebagai pasien.

\section{(2.4) Ketut Sadru nglablab séla di paon panak-né}

Nama merebus ubi di dapur anaknyaPOSS

'Ketut Sadru merebus ubi di dapur anaknya'
A/agen
U/pasien
diberikan ibu-DEF

Data ( 2.4) terdiri dari dua argumen yang memiliki peran sebagai agen dan pasien. Ketut Sadru menduduki peran sebagai agen, karena melakukan pekerjaan nglablab (merebus) dengan proses dari séla (ubi) menjadi séla malablab (ubi yang direbus), sedangkan séla (ubi) memiliki peran khusus yakni sebagai pasien.

\section{(2.5)Pan Bungkling nguskus jagung ibi} sanjané

Nama merebus jagung kemarin sorenyaPOSS

'Pan Bungkling merebus jagung kemarin sorenya'

\section{A/agen \\ U/pasien}

Data (2.5) terdiri dari dua argumen yang memiliki peran sebagai agen dan pasien. Pan Bungkling menduduki peran sebagai agen, karena melakukan pekerjaan ngukus (merebus) dengan proses dari jagung (jagung) menjadi jagung makuskus (jagung 
yang direbus), sedangkan jagung (jagung) memiliki peran khusus yakni sebagai pasien.

\section{(2.6) I Wayan Kancil ngatim bé siap}

Nama memasak daging ayam

'I Wayan Kancil memasak daging ayam
A/agen
U/pasien

Data (2.6) terdiri dari dua argumen yang memiliki peran sebagai agen dan pasien. I Wayan Kancil menduduki peran sebagai agen, karena melakukan pekerjaan ngetim (memasak) dengan proses dari bé siap (daging ayam) menjadi bé siap metim (daging ayam yang dimasak), sedangkan bé siap (daging ayam) memiliki peran khusus yakni sebagai pasien.

\section{(2.7) Ketut Jirna ngnyahnyah jaja gina sambilang nyiup kopi-n-né}

Nama memanggang jajan sambil minum kopinya-DEF

'Ketut Jirna memanggang jajan sambil meminum kopinya'

\section{A/agen U/pasien}

Data (2.7) terdiri dari dua argumen yang memiliki peran sebagai agen dan pasien. Ketut Jirna menduduki peran sebagai agen, karena melakukan pekerjaan ngnyahnyah (memanggang) dengan proses dari jaja gina (jajan Bali) menjadi jaja gina manyahnyah (jajan Bali yang dipanggang), sedangkan jaja gina (jajan Bali ) memiliki peran khusus yakni sebagai pasien.

\section{(2.8) I Mémé nambus séla di tegalé ajak} nyaman-nyama-né Ibu memanggang ubi di ladang bersama saudara-saudaranya-POSS
'Ibu memanggang ubi di ladang bersama saudara-saudaranya'
A/agen
U/pasien

Data (2.8) terdiri dari dua argumen yang memiliki peran sebagai agen dan pasien. I Mémé menduduki peran sebagai agen, karena melakukan pekerjaan nambus (memanggang) dengan proses dari séla (babi) menjadi séla matambus (ubi yang dipanggang), sedangkan séla (ubi) memiliki peran khusus yakni sebagai pasien.

(2.9)Luh Putu ngepés bé pindang di jalikanné

Nama memanggang ikan tongkol di tungku masaknya-POSS

'Luh Putu memanggang ikan tongkol di tungku masaknya'
A/agen
U/pasien

Data ( 2.9) terdiri dari dua argumen yang memiliki peran sebagai agen dan pasien. Luh Putu menduduki peran sebagai agen, karena melakukan pekerjaan ngepés (memanggang) dengan proses dari bé pindang (ikan tongkol) menjadi pésan pindang (ikan tongkol yang dipanggang), sedangkan bé pindang (ikan tongkol) memiliki peran khusus yakni sebagai pasien.

\section{(2.10)Pan Sara ngoréng bé pindang}

Nama menggoreng ikan pindang 'Pan Sara menggoreng ikan pindang' A/agen

U/pasien

(Klungkung)

Data (2.10) Pan Sara menempati peran khusus yakni berupa agen, sedangkan bé pindang (ikan pindang) menempati peran 
khusus yakni pasien. Pan Sara melakukan pekerjaan ngoreng (menggoreng) dengan proses dari be pindang (ikan pindang) menjadi pindang magoreng (ikan pindang digoreng), memiliki peran khusus yakni sebagai pasien.

\section{(2.11)I Pekak nadang jaja sambilanga nyiup kopi-n-né \\ Kakek memanggang jajan sambil minum kopinya-DEF \\ 'Kakek memanggang jajan sambil minum kopinya' \\ A/agen U/pasien}

Data (2.11) terdiri dari dua argumen yang memiliki peran sebagai agen dan pasien. I Pekak menduduki peran sebagai agen, karena melakukan pekerjaan nadang (memanggang) dengan proses dari jaja (jajan) menjadi jaja madadang (jajan yang dipanggang), sedangkan jaja (jajan) memiliki peran khusus yakni sebagai pasien.

\section{SIMPULAN}

Kajian Metabahasa Semantik Alami ini mengkaji aspek semantik, yakni realisasi leksikal dan klasifikasi verba "memasak" dalam bahasa Bali (VMBB) terutama peran khusus semantik argumen VMBB. Penentuan peran-peran argumen VMBB menggunakan teori Peran Umum (Macroroles) mengkaji peran semantik VMBB. Secara umum, $A C T O R$ di dalam VMBB bertindak sebagai agen, UNDERGOER bertindak sebagai pasien. Leksikon Verba Memasak Bahasa Bali (VMBB) ditemukan sebanyak 12 butir yakni nyakan,mubuh, ngoreng, ngepes, ngnyahnyah, nadang, nunu, nambus, ngatim, nguskus, nguling dan nglablab. Hasil penelitian menunjukkan bahwa leksikon-leksikon VMBB memiliki peran khusus yakni sebagai agen dan pasien.

\section{DAFTAR PUSTAKA}

Bawa dan Jendra. 1981. Struktur Bahasa Bali. Jakarta : Pusat Pembinaan dan Pengembangan Bahasa, Departemen Pendidikan dan Kebudayaan.

Booij, Geert, 2005. The Grammar Of Words.Oxford Textbooks in Linguistics.

Chomsky, Noam. 1977. Essays on Form and Interpretation. Amsterdam : North Holland.

Hadi, Sutrisno. 1981. Metodologi Research Jilid I. Yogyakarta : Universitas Gadjah Mada.

Pastika, I Wayan. 1999. Voice Selection in Balinese Narrative Discourse (Ph.D Dissertation). Canberra : The Australian National University.

Samsuri. 1987. Analisa Bahasa. Jakarta : Erlangga

Sudaryanto. 1985. Metode dan Aneka Teknik Analisis Bahasa. Yogyakarta : Duta Wacana University Press.

Sudipa, I Nengah. 2004. "Verba dalam Bahasa Bali : Kajian Metabahasa Semantik Alami”. (disertasi). Denpasar: Universitas Udayana. 
LINGUISTIKA, SEPTEMBER 2018

p-ISSN: 0854-9613

Vol. 49. No. 25

Sudipa, I Nengah. 2010. Struktur Semantik Verba Keadaan Bahasa Bali. Denpasar : Udayana University Press.

Folley, W. A. dan R. D. Van Valin. 1984. Functional Syntax and Universal Grammar. Cambridge : Cambridge University Press.

Van Valin, R. D. dan R. LaPolla. 1999. Syntax : Structure, Meaning, and Function. Cambridge: Cambridge University Press 